\title{
Impact of tank rehabilitation on TMI members of the Karnataka Community Based Tank Management Project
}

\author{
Ashok Doddamani*, C. M. Savitha and M. A. Yashashwini \\ Department of Agricultural Extension, University of Agricultural Sciences, GKVK, \\ Bangalore-560065, India \\ *Corresponding author
}

\section{A B S T R A C T}

\section{Keywords}

Tank rehabilitation, TMI members, Dry zones, Foreshore planting

\section{Article Info}

\section{Accepted:}

12 December 2020

Available Online:

10 January 2021
"Keres" are historical innovations to even out the monsoon irregularities and reduce the risks of uncertainties in water availability in the dry zones. Considering the importance of "keres" in the traditional livelihood systems. The present study was conducted in Bagepalli taluk of Chikballapur district, Mulbagal taluk of Kolar district, Pavagada taluk of Tumkur district and Chitradurga (Kasaba) taluk of Chitradurga district of Karnataka. The study was conducted with 212 respondents. the result reveled that, among 29 particular outcome of tank rehabilitation items only 5 particular items were responded by more than 95 percent of the respondents: rehabilitation of tank executed satisfactorily (98.6\%), foreshore planting was done effectively with increasing in the area (98.1\%), practicing the multiple cropping and the crop diversification, extent of agriculture productivity increased in the command area (95.3\%) and recharging of ground water increased $(95.3 \%)$ were the outcome of tank rehabilitation on TMI members after the tank rehabilitation work. A majority of respondents who replied as 50 per cent impact of tank rehabilitation on TMI members under the project for irrigated area is increased after rehabilitation 58.5 per cent followed by recharging of ground water increased in the project tank command area $(56.1 \%)$.

\section{Introduction}

Tank, meaning "kere" in Kannada, the language people in Karnataka speak, refers to a reservoir of water impounded behind earthen bunds and embankments. The bunds, close off a landscape depression and surround water on the three sides. The seasonal run off from streams and minor rivers drains water into the "kere". The upstream catchment receives rainfall and discharges water which flows down to be collected in the "kere". Embedded in the earthen bund, are water-flow regulating devices called sluices, which let open water downstream through gravity flows. Channels which are distributed over the catchment bring water to irrigate the fields in the ayacut. Typically a "kere" will also have arrangements for overflow of water in case water discharge into the "kere" is beyond the level of the bund can safely hold. These overflow weirs prevent erosion and breaching 
of the bund and hence act as safety valves. More often "keres" is part of the interconnected chain of "keres" cascading water flows from one located in the upstream to those in the downstream.

Traditionally, the farmers were chasing the monsoons to raise crops. "Keres" are historical innovations to even out the monsoon irregularities and reduce the risks of uncertainties in water availability in the dry zones. Considering the importance of "keres" in the traditional livelihood systems, the traditional wisdom and local insights built constructs and concepts of important bodies of knowledge of Jalashastra (hydraulics) and Pathashastra (hydrology). The ancient engineering skills demonstrate the unique competencies of these sciences in designing, constructing as well as maintaining the "keres". The tanks in the past apart from its engineering excellence and irrigation utilities to maintain the village economics have important societal and ecological roles to perform. The tanks in the past were managed by the local communities as the committee of the village assembly. The importance of the tank system to the nation is also evidenced by the involvement of the supra community in managing the affairs of the tank system. Irrigation water released from the tanks have always been considered as an economic good with farmers contributing a percentage of their produce towards maintenance of the tank system and also towards costs involved in water release and regulation. There existed NEERAGANTI system for regulating and rationing water from tanks.

\section{Materials and Methods}

The study was conducted in Bagepalli taluk of Chikballapur district, Mulbagal taluk of Kolar district, Pavagada taluk of Tumkur district and Chitradurga (Kasaba) taluk of Chitradurga district of Karnataka. Since
Bagepalli and Mulbagalu taluks have more number beneficiaries of On-farm demonstrations on water management (WMD), arable crops (ACD), horticultural crops (HCD) and farmer field school(FFS) were selected for the study while Pavagada and Chitradurga taluks did possess less number of beneficiaries of On-farm demonstrations and FFS were selected to match the respondents.

Respondents were selected based on multistage random sampling technique. Sixty beneficiaries from WMD, 60 beneficiaries from $\mathrm{ACD}$ and 32 beneficiaries from HCD were selected based on the on-farm demonstrations conducted at the ratio of $2: 2: 1$ (WMD: ACD: HCD) as per the norms of KCBTMPCS and from FFS also 60 beneficiaries were selected. Thus, the study was conducted with 212 respondents wherein each taluk one village for WMD, one village for $\mathrm{ACD}$, one village for $\mathrm{HCD}$ and one village for FFS was selected based on the highest number of beneficiaries. From each village 15 respondents was selected through random sampling technique. But, in HCD only 8 respondents was selected, constituting a total sample size of 212 .

\section{Results and Discussion}

Nearly 45.00 per cent of FFS respondents had low overall tank rehabilitation impact categories (Fig. 1) followed by medium $(36.67 \%)$ and high $(18.33 \%)$ level categories. Further, 38.33 per cent of WMD respondents are medium level overall tank rehabilitation impact categories followed by high (36.67\%) and low $(25.00 \%)$ categories. More than fifty (58.33\%) per cent of the ACD respondents were high, 28.33 per cent had medium and only 13.33 per cent of low overall tank rehabilitation impact categories. Equal (40.63\%) number of respondents from HCD had low and high overall tank rehabilitation 
impact categories followed 18.75 per cent had medium overall tank rehabilitation impact categories. An over view of among all respondents the overall total tank rehabilitation impact were, 37.74 per cent fall in the high level categories followed by medium $(32.55 \%)$ and low $(29.72 \%)$ level categories. The possible reason for majority of the respondents belonging to the high to medium level of overall impact of tank rehabilitation category might be due to the fact that, de-siltation of tank system, rectification of tank bund, rectification of tank sluice, increased height and condition of waste weir, improvement of feeder channel, foreshore planting and vacation of encroachment of tank bed area activities were attempted under the project. The other reason might be that, cow, buffalo and goat/sheep were distributed at free of cost to the selected TMI members, and IGA were supported and training given to respondents to go for such IGA in the project area and majority of the farmers were applied silt to their farm by this their crop productivity and income was increased through tank rehabilitation.

A critical glance at table 1, recalls the distribution of respondents according to tank rehabilitation impact on TMI members of the project. The result shows that, after the tank rehabilitation work cent percent respondents expressed their views to the following particular items: Household income of the TMI stake holders increased, communities are involved in planning and coordinating technical support for the ITDPs, in the upgraded tank command area the income was improved, the irrigated area is increased after rehabilitation, encroachment related conflicts were amicably resolved by TMIs in accordance with the government of Karnataka (GOK) policy. The tank siltation is reduced after rehabilitation, irrigation potential was restoring after rehabilitation of the tank and under the project many activities like, multiple cropping, crop diversification, livestock rearing, fisheries etc, are open up and would provide the gainful employment opportunities. Among 29 particular outcome of tank rehabilitation items only 5 particular items were responded by more than 95 percent of the respondents: rehabilitation of tank executed satisfactorily (98.6\%), foreshore planting was done effectively with increasing in the area $(98.1 \%)$, practicing the multiple cropping and the crop diversification, extent of agriculture productivity increased in the command area $(95.3 \%)$ and recharging of ground water increased $(95.3 \%)$ were the outcome of tank rehabilitation on TMI members after the tank rehabilitation work. As expressed by 13.70 percent,28.8 percent, 49.5 percent and 33.5 percent respondents with respect to foreshore planting was done effectively with increasing the area, adopting the multiple cropping and crop diversification, extent of agriculture productivity is increased in the command area and recharging of ground water, respectively before tank rehabilitation work.

Regarding foreshore, it was seen that after tank rehabilitation work there was an improvement in livelihoods, reduction of poverty through tank rehabilitation system (94.3\%), practicing the double cropping and improved farming practices $(92.6 \%)$, water level increased in the surrounding wells/bore wells due to recharging effect of the tanks (94.3\%), tank rehabilitated as per the technical and engineering specifications $(91.0 \%)$ and poor men and women are getting good place in management position both in TMI \& TUGs $(90.1 \%)$. As an outcome of tank rehabilitation only 56.1 percent respondents had opinion that improvement in livelihoods and reduction of poverty through tank rehabilitation followed by practicing multiple cropping and crop diversification(48.1\%), practicing the double cropping and improved farming practices and 
water level increased in the well/bore wells $(11.3 \%)$. A great majority of the respondents $(87.7 \%)$ were self managed and sustainable Tank Users Groups are established followed by project provided an opportunity to go for high value crops and fruit crops to increase the income $(84.4 \%)$, extent of cropped area increased in command area $(89.6 \%)$, implemented the strategy approved by TMI which includes water use and cropping plan, for collection of plan for operation and maintenance and off shore maintenance schedules (83.5\%), land less tank users as members of SHGs beneficiaries from IGAs $(82.1 \%)$, project implementation procedures and fiduciary aspects which are effectively facilitated $(75.0 \%)$, savings generated and credit disbursed to SHGs women and other marginalized communities under the project (74.5\%), practicing the livestock rearing as a result of tank rehabilitation $(73.6 \%)$ and 53.3 percent respondents are using the tank water for fishery activities /brick making as for the tank rehabilitation are the outcome impact of tank rehabilitation on TMI members under the project.

As could be seen from the table 1 before and after the tank rehabilitation, $98.6 \%$ of respondents had indicated rehabilitation of tank executed satisfactorily followed by irrigation area is increased after rehabilitation $(95.3 \%)$, irrigation potential was restoring after the rehabilitation of the tank (93.4\%), traditionally marginalized tank users organized under the TMI in the rehabilitated tank command area and production was increased $(87.7 \%)$,foreshore planting was done effectively with increasing in the area $(84.4 \%)$, TMI and TUGs are established voluntarily after the PRA and PLA activities facilitated by the CFTs $(83.0 \%)$, water level increased in the surrounding wells/bore wells due to the recharging effect of the tank $(82.1 \%)$, self managed and sustainable tank users groups are established $(81.6 \%)$, project implementation procedures and judiciary aspects which are effectively facilitated $(75.0 \%)$, landless tank users income increased in the project tank command area $(66.8 \%)$, landless tank users as members of SHGs benefiting from the IGA $(63.7 \%)$, agricultural area increased in the command area $(61.8 \%)$ and agricultural productivity increased in the command area $(59.9 \%)$.

\section{$25 \%$ impact}

A critical view from table 1 revels that, $25 \%$ of impact of tank rehabilitation on TMI members of the project on improved in livelihoods and reduction of poverty through tank rehabilitation system was expressed by 74.1 per cent respondents followed by cropped area increased in the command area (65.1\%), households incomes of the TMI stakeholders increased (63.2\%), traditionally marginalized tank users organized under the TMI in the rehabilitated tank command area and production was increased (47.6\%), upgraded tank command area the income was improved $(44.8 \%)$, poor men and women are getting the good place in the management position both in the TMIs and TUGs (41.0\%), implemented the strategy approved by TMIs (38.2\%), TMIs and TUGs are established voluntarily after the PRA and PLA activities facilitated by the CFTs $(33.00 \%)$, irrigation potential was restoring after the rehabilitation of the tank (32.5\%), communities are involved in planning and coordinating technical support for the ITDPS, project was provided/supported an opportunities to go for high value crops and fruit crops to increase the income $(27.4 \%)$ and using the tank water for fishery activities or brick making (24.1\%).

\section{$50 \%$ impact}

A majority of respondents who replied as 50 per cent impact of tank rehabilitation on TMI members under the project for irrigated area is 
increased after rehabilitation 58.5 per cent followed by recharging of ground water increased in the project tank command area $(56.1 \%)$, water level increased in the surrounding wells/bore wells due to the recharging effect of the tanks $(56.1 \%)$ and upgraded tank command area income was improved (50.5\%). Further, 38.7 per cent respondents opined that 50 per cent impact of tank rehabilitating on TMI members on tanks siltation is reduced after rehabilitation work followed by practicing the multiple cropping and crop diversification (38.2\%), multiple cropping, crops diversification, livestock rearing and fisheries etc, are open up and would provide the gainful employment opportunities (35.4\%), saving generated and credit disbursed to SHGs of women and other marginalized communities under the project (34.4\%), landless tank users as members of SHGs benefiting from the IGA (34.0\%), encroachment related conflicts are amicably resolved by TMI in accordance with the GOK policy $(32.1 \%)$, irrigation potential was restoring after the rehabilitation of the tank $(32.1 \%)$, project implementation procedures and fiduciary aspects which are effectively facilitated $(29.2 \%)$, practicing the livestock rearing as a result of tank rehabilitation $(28.8 \%)$ and income generated annually satisfactory (23.1\%). While, 11.3 per cent and 15.1 per cent of the respondents expressed that 50 per cent impact of tank rehabilitation on TMI and TUGs are established voluntarily after the PRA and PLA activities facilitated by the CFTs and tank rehabilitation as per the technical and engineering specification, respectively.

\section{$75 \%$ impact}

Table 6 reveled that, 75 per cent impact of tank rehabilitation on TMI members was found. A good majority of the respondents $(50.00 \%)$ expressed that rehabilitation of tank executed satisfactory followed by practicing the double cropping and improved farming practice $(46.2 \%)$, foreshore planting was done effectively with increasing in the area $(37.3 \%)$, self managed and sustainable tank users groups are established (36.8\%) and tanks rehabilitated as per the technical and engineering specification (26.4\%). However, a few and same (4.7\% each) number of respondents opined that, household income of the TMI stakeholders increased, upgraded tank command area the income was improved and landless tank users income increased through IGA and the irrigated area increased after tank rehabilitation. Further traditional marginalized tank users organized under the TMI in the rehabilitated tank command area and production increased (13.7\%) was expressed by the respondents as indicated 75 per cent impact of tank rehabilitation on TMI members under the project.

\section{$100 \%$ impact}

A few respondents were indicating 100 per cent impact of tank rehabilitation on TMI members under the project on recharging of ground water increased in the project tank command area (2.8\%), followed by equal (4.2 $\%)$ number of respondents stated that poor $\mathrm{men} /$ women are getting the good place in management position both in the TMI and TUGs and income generated annually satisfactory, practicing the live stock rearing as a result of rehabilitation (5.7\%) and water level increased in the surrounding wells/bore wells due to the recharging effect on tanks $(7.1 \%)$. Further, the same response $(8.5 \%)$ was given by the respondents to project implementation procedures and fiduciary aspects which are effectively facilitates, landless tank users as members SHGs benefitting from the IGA and saving generated and credit disbursed to SHGs of women and other marginalized communities under the project. While, 10.8 per cent respondents said that tank siltation is reduced 
after rehabilitation followed by encroachment related conflicts are amicably resolved by TMIs in accordance with the GOK policy (12.7\%), TMI and TUGs are established voluntarily after the PRA and PLA activities facilities by the CFTs, irrigation potential was restoring after the rehabilitation of the tank $(13.7 \%)$, foreshore planting was done effectively with increasing in the area $(14.2 \%)$, rehabilitation of tank executed satisfactory $(15.6 \%)$ and communities are involved in planning and coordinating technical support for the ITDPs $(19.8 \%)$ and also establishment of self managed and sustainable tank users groups $(19.8 \%)$.

In Karnataka selected tanks were rehabilitated and rejuvenated with the financial support from the World Bank through KCBTMP. The respondents of this study, in general, expressed that the impact of tank rehabilitation on TMI members was seen improvement of tanks in accordance with engineering specification, reeducation in siltation, increase in water storage in the tank, removal of encroached land in tank beds and setting of related conflicts amicably, expansion of area under cultivation in the commanded area due to improvement in irrigation water supply through tanks and open/bore wells, helps in crop diversification, multiple cropping and crop rotation to secure higher productivity, total agricultural production gainful employment through livestock rearing, fisheries and other subsidiary enterprises, additional income through foreshore plantation covered in large area in long run, supporting landless tank users and SHGs members through appropriate IGA, getting financial assistance through revolving fund and credit from banks to SHGs members and other persons of marginalized communities and such benefits.

Again, the respondents were differed in recording their responses regarding impact of tank rehabilitation ranging from 25.00 per cent impact to 100.00 per cent impact. The respondents who stated 25.00 per cent impact have seen improvement in livelihoods and reduction in poverty of TUGs members, expansion of cultivated area in the tank commands, increase in productivity and production of crops in the command area, implement in irrigation potential after tank rehabilitation, offering better management position to members economically backward weaker sections of the society and involving them in planning and implementation of activities include in ITDPs.

Regarding the respondents who expressed as 50.00 per cent of impact was observed after tank rehabilitation, points out that there was an increase in the cropped area in the tank commands, increase in underground water level in the open/bore wells in the surrounding area due to recharging of ground water, reduction in siltation enabling more water storage in tanks, introduction of crop diversification and multiple cropping system instead of mono cropping in the command area due to storage of more water in tanks and wells/bore wells, increased income and gainful employment from crop and livestock enterprises, gaining employment and income to SHG members and landless tank users through suitable IGA and resolving conflicts related to encroachment matters at TMI level. These benefits came to the doorsteps of TMI members because of tank rehabilitation activity carried out under KCBTMP.

In case of respondents reporting the reasons for such an impact were establishment of self and well managed sustainable tank users groups, carrying out tank rehabilitation work as per technical and engineering specifications, executing the tank rehabilitation work satisfactory with the collective and coordinated efforts by TUG members, introduction and practicing of 
double/multiple cropping system adopting latest crop production technologies to get increased farm income, effective foreshore planting with increased area, increased income to marginalized tank users and securing higher income to SHG members and landless tank users from proper IGA.

These were the main reasons for the respondents to witness 75.00 per cent impact of tank rehabilitation.

Some respondents even stated that there was 100.00 per cent impact of tank rehabilitation for the reasons that self managed and sustainable TUCs and TUGs were well established under the guidance of CFTs, executing tank rehabilitation work satisfactorily with the good cooperation of TMI members as recorded in ITDP, creation of irrigation potential due to de-siltation in tank, better utilization of tank bed area with required foreshore planting covering useful forest and fruit trees, improvement in ground water recharge enabling increasing in water level in the surrounding open wells/bore wells which in turn helps in increasing agricultural production in the command area, settling encroachment problems and conflicts amicably with the cooperation of the party who encroached the tank beds, landless tank users received handsome income through implementation of useful IGA activities with the financial assistance in the form of loan from revolving fund of TMIs and loan facilities extended by financial institutions like banks to improve their economy by undertaking suitable subsidiary enterprises and business related activities.

Fig.1 Overall Impact level of rehabilitation of tank system on TMI members

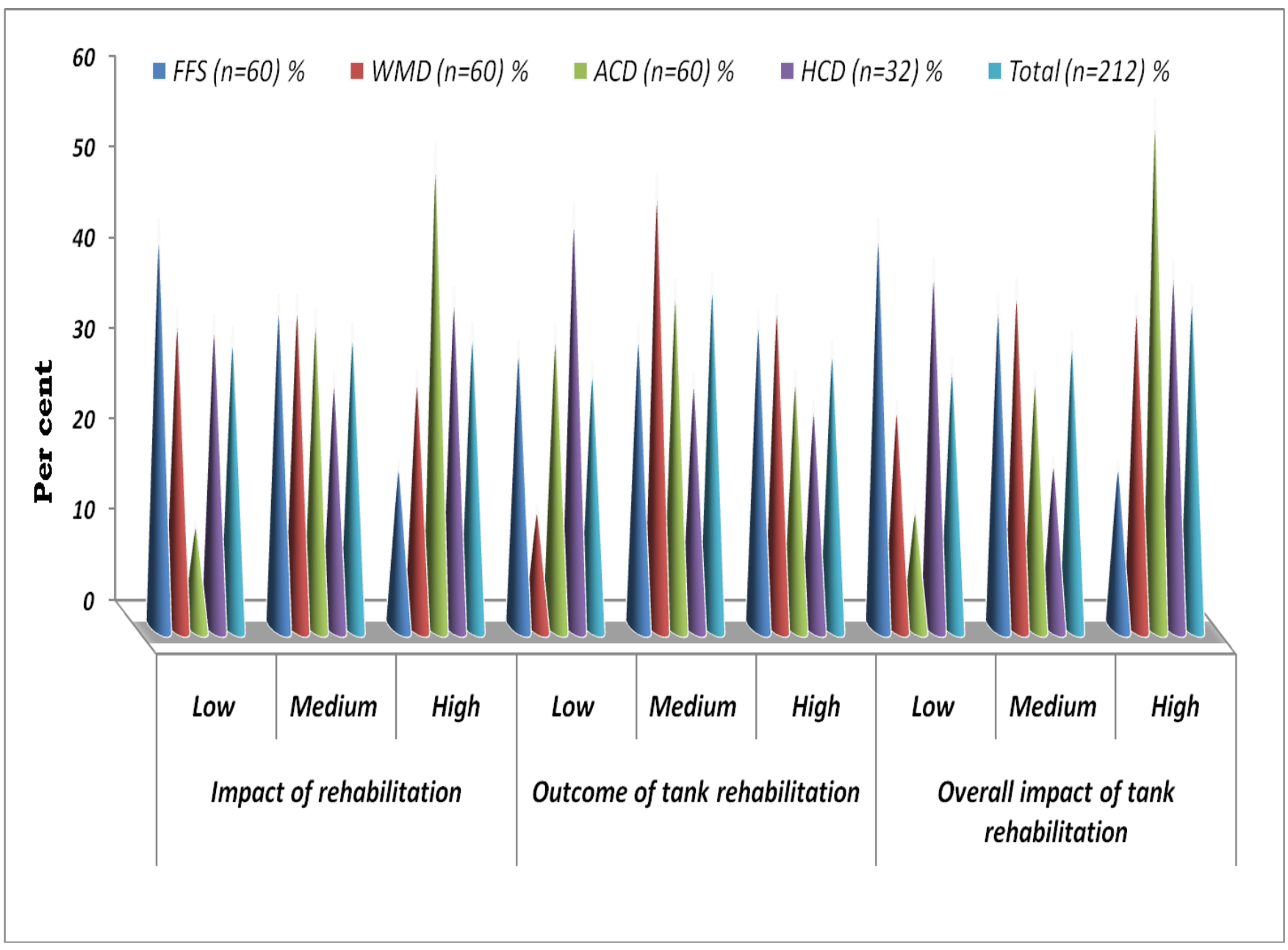


Table.1 Impact of tank rehabilitation on TMI members of the Project

\begin{tabular}{|c|c|c|c|c|c|c|c|c|c|c|c|c|c|c|c|}
\hline \multirow{4}{*}{$\begin{array}{l}\text { Sl. } \\
\text { No. }\end{array}$} & \multirow{4}{*}{ Particulars } & \multirow{2}{*}{\multicolumn{4}{|c|}{$\begin{array}{c}\text { Outcome of tank } \\
\text { rehabilitation }\end{array}$}} & \multirow{3}{*}{\multicolumn{2}{|c|}{$\begin{array}{l}\text { Additional } \\
\text { outcome }\end{array}$}} & \multirow{2}{*}{\multicolumn{8}{|c|}{ Impact Percent (\%) }} \\
\hline & & & & & & & & & & & & & & & \\
\hline & & \multicolumn{2}{|c|}{ Before } & \multicolumn{2}{|c|}{ After } & & & \multicolumn{2}{|c|}{25} & \multicolumn{2}{|c|}{50} & \multicolumn{2}{|c|}{75} & \multicolumn{2}{|c|}{100} \\
\hline & & $\mathbf{F}$ & $\mathbf{P}$ & $\mathbf{F}$ & $\mathbf{P}$ & $\mathbf{F}$ & $\mathbf{P}$ & $\mathbf{F}$ & $\mathbf{P}$ & $\mathbf{F}$ & $\mathbf{P}$ & $\mathbf{F}$ & $\mathbf{P}$ & $\mathbf{F}$ & $\mathbf{P}$ \\
\hline 1. & $\begin{array}{l}\text { Improvement in your livelihoods and } \\
\text { reduction of poverty through tank } \\
\text { rehabilitation system }\end{array}$ & 119 & 56.1 & 200 & 94.3 & 81.0 & 38.2 & 157 & 74.1 & 43 & 20.3 & 12 & 5.7 & 0 & 0.0 \\
\hline \multirow[t]{3}{*}{2.} & $\begin{array}{l}\text { Extent of agriculture production } \\
\text { increased in the command area }\end{array}$ & & & & & & & & & & & & & & \\
\hline & i) Productivity & 63 & 29.7 & 190 & 89.6 & 127.0 & 59.9 & 138 & 65.1 & 54 & 25.5 & 0 & 0.0 & 0 & 0.0 \\
\hline & ii) Area & 71 & 33.5 & 202 & 95.3 & 131.0 & 61.8 & 156 & 73.6 & 56 & 26.4 & 0 & 0.0 & 0 & 0.0 \\
\hline 3. & $\begin{array}{l}\text { Household incomes of the TMI } \\
\text { stakeholders increased }\end{array}$ & 0 & 0.0 & 212 & 100.0 & 212.0 & 100.0 & 134 & 63.2 & 68 & 32.1 & 10 & 4.7 & 0 & 0.0 \\
\hline 4. & $\begin{array}{l}\text { Communities are involved in } \\
\text { planning and coordinating technical } \\
\text { support for the ITDPs }\end{array}$ & 0 & 0.0 & 212 & 100.0 & 212.0 & 100.0 & 63 & 29.7 & 56 & 26.4 & 51 & 24.1 & 42 & 19.8 \\
\hline \multirow[t]{2}{*}{5.} & $\begin{array}{l}\text { Self-managed and sustainable tank } \\
\text { users groups are established }\end{array}$ & 13 & 6.1 & 186 & 87.7 & 173.0 & 81.6 & 31 & 14.6 & 35 & 16.5 & 78 & 36.8 & 42 & 19.8 \\
\hline & $\begin{array}{l}\text { Percentage of traditionally } \\
\text { marginalized tank users organized } \\
\text { under the TMI in the rehabilitated } \\
\text { tank command area and increased in } \\
\text { the production (major crops) }\end{array}$ & 0 & 0.0 & 186 & 87.7 & 186.0 & 87.7 & 101 & 47.6 & 56 & 26.4 & 29 & 13.7 & 0 & 0.0 \\
\hline 6. & $\begin{array}{l}\text { Upgraded tank command area the } \\
\text { income was improved }\end{array}$ & 0 & 0.0 & 212 & 100.0 & 212.0 & 100.0 & 95 & 44.8 & 107 & 50.5 & 10 & 4.7 & 0 & 0.0 \\
\hline 7. & $\begin{array}{l}\text { Landless tank users income } \\
\text { increased by through IGA }\end{array}$ & 16 & 7.5 & 168 & 79.2 & 152.0 & 71.7 & 114 & 53.8 & 44 & 20.8 & 10 & 4.7 & 0 & 0.0 \\
\hline 8. & $\begin{array}{l}\text { Implemented the strategy approved by the } \\
\text { TMI, which include water use and }\end{array}$ & 0 & 0.0 & 177 & 83.5 & 177.0 & 83.5 & 81 & 38.2 & 57 & 26.9 & 39 & 18.4 & 0 & 0.0 \\
\hline
\end{tabular}




\begin{tabular}{|c|c|c|c|c|c|c|c|c|c|c|c|c|c|c|c|}
\hline & $\begin{array}{l}\text { cropping plan, for collection of plan for } \mathrm{O} \\
\& \mathrm{M} \text {, and offshore maintenance schedules }\end{array}$ & & & & & & & & & & & & & & \\
\hline 9. & $\begin{array}{l}\text { Followed the project implementation } \\
\text { procedures and fiduciary aspects } \\
\text { which are effectively facilitated }\end{array}$ & 0 & 0.0 & 159 & 75.0 & 159.0 & 75.0 & 50 & 23.6 & 62 & 29.2 & 29 & 13.7 & 18 & 8.5 \\
\hline 10. & $\begin{array}{l}\text { TMI and TUGs are established } \\
\text { voluntarily after the PRA and PLA } \\
\text { activities facilitate by the CFTs }\end{array}$ & 0 & 0.0 & 176 & 83.0 & 176.0 & 83.0 & 70 & 33.0 & 24 & 11.3 & 55 & 25.9 & 27 & 12.7 \\
\hline 11. & $\begin{array}{l}\text { Landless tank users (disaggregated } \\
\text { by cast, tribe and gender) as } \\
\text { members of SHGs benefiting from } \\
\text { the IGA }\end{array}$ & 39 & 18.4 & 174 & 82.1 & 135.0 & 63.7 & 57 & 26.9 & 72 & 34.0 & 27 & 12.7 & 18 & 8.5 \\
\hline 12. & $\begin{array}{l}\text { Poor men/ women are getting the } \\
\text { good place in management position } \\
\text { both in the TMIs and TUGs }\end{array}$ & 0 & 0.0 & 191 & 90.1 & 191.0 & 90.1 & 87 & 41.0 & 53 & 25.0 & 42 & 19.8 & 9 & 4.2 \\
\hline 13. & $\begin{array}{l}\text { Tanks rehabilitated as per the } \\
\text { technical and engineering } \\
\text { specification }\end{array}$ & 0 & 0.0 & 193 & 91.0 & 193.0 & 91.0 & 51 & 24.1 & 32 & 15.1 & 56 & 26.4 & 54 & 25.5 \\
\hline 14. & $\begin{array}{l}\text { Irrigated area is increased after } \\
\text { rehabilitation }\end{array}$ & 10 & 4.7 & 212 & 100.0 & 202.0 & 95.3 & 78 & 36.8 & 124 & 58.5 & 10 & 4.7 & 0 & 0.0 \\
\hline 15. & $\begin{array}{l}\text { Practicing the multiple cropping and } \\
\text { crop diversification }\end{array}$ & 102 & 48.1 & 205 & 96.7 & 103.0 & 48.6 & 42 & 19.8 & 81 & 38.2 & 57 & 26.9 & 25 & 11.8 \\
\hline 16. & $\begin{array}{l}\text { Practicing the double cropping and } \\
\text { improved farming practices }\end{array}$ & 86 & 40.6 & 197 & 92.9 & 111.0 & 52.4 & 30 & 14.2 & 69 & 32.5 & 98 & 46.2 & 0 & 0.0 \\
\hline \multirow[t]{2}{*}{17.} & $\begin{array}{l}\text { Using the tanks water for fishery } \\
\text { activities or brick making }\end{array}$ & 38 & 17.9 & 113 & 53.3 & 75.0 & 35.4 & 51 & 24.1 & 32 & 15.1 & 20 & 9.4 & 10 & 4.7 \\
\hline & $\begin{array}{l}\text { Rs. Income generated annually } \\
\text { satisfactory }\end{array}$ & 17 & 8.0 & 113 & 53.3 & 96.0 & 45.3 & 34 & 16.0 & 49 & 23.1 & 21 & 9.9 & 9 & 4.2 \\
\hline 18. & $\begin{array}{l}\text { Practicing the livestock rearing as a } \\
\text { result of tank rehabilitation }\end{array}$ & 89 & 42.0 & 156 & 73.6 & 67.0 & 31.6 & 51 & 24.1 & 61 & 28.8 & 32 & 15.1 & 12 & 5.7 \\
\hline 19. & $\begin{array}{l}\text { Water level increased in the } \\
\text { surrounding wells/bore wells due to }\end{array}$ & 24 & 11.3 & 198 & 93.4 & 174.0 & 82.1 & 25 & 11.8 & 119 & 56.1 & 39 & 18.4 & 15 & 7.1 \\
\hline
\end{tabular}




\begin{tabular}{|c|c|c|c|c|c|c|c|c|c|c|c|c|c|c|c|}
\hline & the recharging effect of the tanks & & & & & & & & & & & & & & \\
\hline 20. & $\begin{array}{l}\text { Encroachment related conflicts are } \\
\text { amicably resolved by TMIs in } \\
\text { accordance with the GOK policy }\end{array}$ & 0 & 0.0 & 212 & 100.0 & 212.0 & 100.0 & 58 & 27.4 & 68 & 32.1 & 58 & 27.4 & 27 & 12.7 \\
\hline 21. & $\begin{array}{l}\text { Saving generated and credit } \\
\text { disbursed to SHGs of women and } \\
\text { other marginalized communities } \\
\text { under the project }\end{array}$ & 0 & 0.0 & 158 & 74.5 & 158.0 & 74.5 & 45 & 21.2 & 73 & 34.4 & 22 & 10.4 & 18 & 8.5 \\
\hline 22. & $\begin{array}{l}\text { The tanks siltation is reduced after } \\
\text { rehabilitation }\end{array}$ & 0 & 0.0 & 212 & 100.0 & 212.0 & 100.0 & 72 & 34.0 & 82 & 38.7 & 35 & 16.5 & 23 & 10.8 \\
\hline 23 & $\begin{array}{l}\text { Irrigation potential was restoring } \\
\text { after the rehabilitation of the tank }\end{array}$ & 14 & 6.6 & 212 & 100.0 & 198.0 & 93.4 & 69 & 32.5 & 68 & 32.1 & 46 & 21.7 & 29 & 13.7 \\
\hline 24. & $\begin{array}{l}\text { Under the project many activities } \\
\text { like, multiple cropping, crop } \\
\text { diversification, livestock rearing, } \\
\text { fisheries etc., are open up and would } \\
\text { provide the gainful employment } \\
\text { opportunities }\end{array}$ & 105 & 49.5 & 212 & 100.0 & 107.0 & 50.5 & 56 & 26.4 & 75 & 35.4 & 49 & 23.1 & 32 & 15.1 \\
\hline 25. & $\begin{array}{l}\text { The project was provided an } \\
\text { opportunity to go for high value } \\
\text { crops and fruit crops to increase the } \\
\text { income }\end{array}$ & 84 & 39.6 & 179 & 84.4 & 95.0 & 44.8 & 58 & 27.4 & 48 & 22.6 & 50 & 23.6 & 23 & 10.8 \\
\hline 26. & $\begin{array}{l}\text { Recharging of ground water } \\
\text { increased in the project tank } \\
\text { command area }\end{array}$ & 61 & 28.8 & 202 & 95.3 & 141.0 & 66.5 & 32 & 15.1 & 119 & 56.1 & 45 & 21.2 & 6 & 2.8 \\
\hline 27. & $\begin{array}{l}\text { Rehabilitation of tank executed } \\
\text { satisfactorily }\end{array}$ & 0 & 0.0 & 209 & 98.6 & 209.0 & 98.6 & 29 & 13.7 & 44 & 20.8 & 106 & 50.0 & 33 & 15.6 \\
\hline 28. & $\begin{array}{l}\text { Foreshore planting was done } \\
\text { effectively with increasing in the } \\
\text { area }\end{array}$ & 29 & 13.7 & 208 & 98.1 & 179.0 & 84.4 & 43 & 20.3 & 60 & 28.3 & 79 & 37.3 & 30 & 14.2 \\
\hline
\end{tabular}


By and large, Karnataka Community Based Tank Management Project (KCBTMP) with the financial assistance from the World Bank under implementation through Jala Samvardhane Yojana Sangha (JSYS) has brought remarkable improvements in rejuvenating of tanks by undertaking tank rehabilitation works with the active involvement of TMIs, CFTs (Cluster Facilitative Teams) and agricultural universities. The rehabilitation of tank had great impact on TMI members for the reason that it helps in repairing tank bunds, waster weirs, sluices and irrigation channels, desiltation to increase more water storage capacity in tanks, afforestation in tank beds by foreshore planting bringing more area under cultivation in the tank command with efficient water management practices, increasing agricultural production and income through crop diversification, multiple cropping and crop rotation practices with the adoption of improved production technologies clubbed with undertaking live stock enterprises, providing gainful employment and also to improve the economic conditions of SHG members and landless tank users through appropriate IGA activities with credit support, besides encouraging TMI members to shoulder the responsibility to manage their tanks leading to sustainability and more useful to the community in a long run. The findings of the study are in line with the study of Hazra (1998), Singh (1990), Soundarapandian (1991), Sridhar (2002), ETC, India (2004), Anonymous (2005), Dolli (2006) and Rais et al., (2007).

\section{References}

Anonymous, 2005, Quick evaluation of beneficiary oriented $(\mathrm{Sc} / \mathrm{St})$ Programme of SGRY; Annual Report. Ministry of Rural Development, Government of India, KrishiBhavan, New Delhi.

Dolli, S. S., 2006, Sustainability of natural resources management in watershed development project. . Ph.D. Thesis, Uni. Agric. Sci. Dharwad.

ETC India, 2004, Report on environmental impact assessment of KAWAD watersheds. ETC consultants India Pvt. Ltd., Bangalore.

Hazra, C. R., 1998, Management of rainwater resources on watershed basis for sustainable agriculture production - An experience of Tejpur Watershed (Jhansi). Agric. Situation in India, 55 (3):120-128.

Rais Uddin Mian, Jamatul Fatema and Habibur Rahman, 2007, Impact of dairy farming on livelihood of participating women under Grameen Bank in a selected area of Rangpur district in Bangladesh. Indian J. Agric. Econ.,62(2): 259-271.

Singh, M. P., 1990, Rainfed agro-technology on watershed basis - A case study. Indian J. Ext. Edu.,,26(3\&4) : 47-52.

Soundarapandian, M., 1991, Impact of TRYSEM and VSR on poverty education in Kamaraja district of Tamil Nadu. Khadi Gramodyog, 37(7): 266-271.

Sridhar, K., 2002, An evaluative study of watershed programme in Paragada taluk of Tumkur district in Karnataka. M. Sc. (Agri.) Thesis, Uni. Agric. Sci. Dharwad.

\section{How to cite this article:}

Ashok Doddamani, C. M. Savitha and Yashashwini, M. A. 2021. Impact of tank rehabilitation on TMI members of the Karnataka Community Based Tank Management Project. Int.J.Curr.Microbiol.App.Sci. 10(01): 1810-1820. doi: https://doi.org/10.20546/ijcmas.2021.1001.211 